九州大学学術情報リポジトリ

Kyushu University Institutional Repository

\title{
A NEW TRIPHLEBA SPECIES WITH BIFURCATE ANTENNAE FROM JAPAN (DIPTERA, PHORIDAE)
}

Goto, Tadao

Takeno, Koichi

https://doi.org/10.5109/2443

出版情報: ESAKIA. 20，pp.149-156，1983-12-15. Entomological Laboratory，Faculty of Agriculture, Kyushu University バージョン：

権利関係 : 


\title{
A NEW TRIPHLEBA SPECIES WITH BIFURCATE ANTENNAE FROM JAPAN (DIPTERA, PHORIDAE) ${ }^{1), 2)}$
}

\author{
TADAO GoTô \\ Entomological Laboratory, Faculty of Agriculture, \\ Kyushu University, Fukuoka 812, Japan \\ and \\ Kôrchr TAKENO \\ Hikosan Biological Laboratory, Faculty of Agriculture, \\ Kyushu University, Hikosan, Fukuoka 824-07, Japan
}

\begin{abstract}
Triphleba schistoceros sp. nov. is described and illustrated from Japan. The species is very unique in its bifurcate 3 rd antennal segments. A short comment on the systematic position of Triphlebanipponica Schmitz is also included.
\end{abstract}

In recent years the senior author have had a good opportunity to examine the phorid flies in the collection of the Hikosan Biological Laboratory, Kyushu University and he found a remarkable new species of the subfamily Phorinae among them. It is represented by 3 males and 1 female, which were collected by the junior author (KT) with a Malaise trap set up on the slope of Mt. Hikosan, Fukuoka Pref.. Kyushu.

In the keys to the genera of Phorinae (Schmitz, 1929, 1941; Borgmeier, 1963), this species runs to the genus Triphleba Rondani, 1856 on the basis of the venation and chaetotaxy of legs. The male of the species is, however, quite different from those of the genus in having the bifurcate 3rd antenna1 segment and strongly widened and shortened frons. Particularly the furcation of 3rd antenna1 segment is a very unique feature in the Phoridae. Such morphological differences from Triphleba appear to give warrant for the erection of a new genus in the present classification of the Phoridae. But it is

1) Contribution from the Entomological Laboratory, Faculty of Agriculture, Kyushu University, Fukuoka (Ser. 3 No. 138).

2) Contribution from the Hikosan Biological Laboratory, Faculty of Agriculture, Kyushu University, Hikosan (Ser. 3 No. 4). 
preferable to place the new species in the genus Triphleba (including Citrago)* because it is identical with the known species of the genus in the basic structure of the male genitalia which sharply distinguishes Triphleba from its allied genera.

The genus Triphleba contains more than 70 species at present and is widely distributed in the world except for the Neotropical and Afrotropical Regions. In Japan Triphlebanipponica Schmitz, 1951 from Tokyo is only one known species of the genus. It is, however, distinctly different from the other Triphleba sepcies in having the short haired vein $\mathrm{Rs}$, the articulated right surstylus and the bridge beneath the anal tube ("Brücke" of Schmitz 1951, see his Fig. I, 2-B) in the male genitalia. Hence reference to Triphleba would appear doubtful. Although the authors have not examined its typespecimen, T. nipponica appears to be an Anevrina species, judging from the above referred features.

Before going further the authors wish to express their hearty thanks to Prof. Y. Hirashima and Assoc. Prof. K. Morimoto of the Entomological Laboratory, Kyushu University for their constant encouragements. They are also deeply indebted to Prof. T. Saigusa of the Biological Laboratory, Kyushu University for his critical reading of the manuscript and kind suggestions in taking photographs. Their cordial thanks are due to Assoc. Prof. M. T. Chûjô of the Hikosan Biological Laboratory, Kyushu University for his kind permission to examine the phorid flies in the collection of the laboratory and his constant encouragement.

\section{Triphleba schistoceros sp. nov.}

M ale. Head black, compressed, as wide as thorax. Compound eye minutely haired. Frons black, thinly grayish brown pollinose, very widened and shortened, at the level of mediolateral seta 0.66-o. 70 of head width, 4. 2-4.6x as wide as long, without median furrow. Chaetotaxy : Anterolateral seta absent; preocellar seta slightly ventral to mediolateral, distance between preocellar setae about $1 / 2$ of that between preocellar and mediolateral ones; posterolateral seta inserted slightly inwardly to mediolateral, in one specimen an extra seta present just outside posterolateral (see Fig. 1, A) ; preocellar, mediolateral and posterolateral setae subequal in length to each other; antial seta ventral to preocellar and slightly shorter than it; supra-antenna1 seta weak, $1 / 3$ of antial in length, in one specimen a pair of bristly hairs recognizable just above supra-antenna1 (see Fig. 1, A) ; several fine frontal setulae scattered. Face distinctly produced between antenna1 sockets. Gena with several bristly hairs. Occiput bearing many bristly hairs on its lateral por-

* The genus Citrago Schmitz, 1924 was synonymized with Triphleba by Disney (1982). The authors follow his treatment. 
tion. Lower postocular seta differentiated. Antenna dull black, slightly tinged with brown; 1st antenna1 segment distinctly elongated, $3 \mathrm{x}$ as long as basal (largest) width, obliquely truncate at apex. Third antenna1 segment characteristic, enlarged, $1.6 \times$ as long as head height, furcated into a pair of haired long processes on distal $7 / 10$, outer one of which bears a pubescent arista at its proximal $1 / 3$; the proximal portion of the segment except for the processes semicircular in lateral view, as long as wide, compressed laterally, thus somewhat rectangular in ventral or dorsal view, entirely long haired, on its inner surface carrying about 7 annular organs measuring 20-25 $\mu$ in diameter. Palpus dull black, grayish brown pollinose, parallel-sided, $6 \mathrm{x}$ as long as wide, with about 15 short bristles on its ventral portion. Epistoma produced forward to form a narrow rectangular plate. Proboscis of ordinary type ; clypeus articulated with epistoma on its anterior margin, weakly membranized on median portion ; labrum triangular in shape ; labellum large, with 6 pairs of pseudotracheae; prementum quadrate in shape.

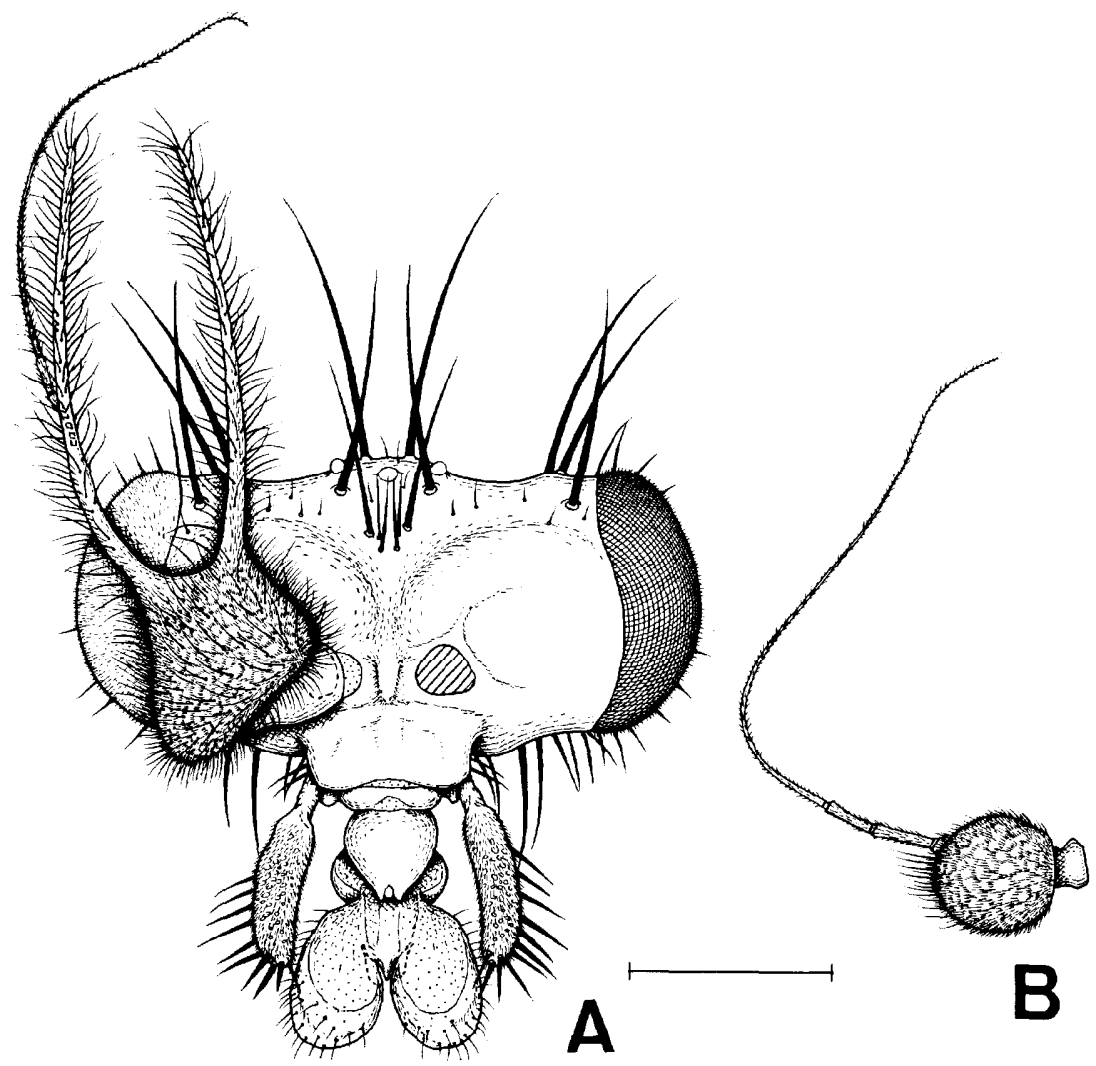

Fig. 1. Triphleba schistoceros sp. $\mathrm{n}$ ov. A: Male head in frontal view. B: Female antenna in lateral view. Scale: $0.3 \mathrm{~mm}$. 
Thorax blackish brown, thinly grayish brown pollinose except for polished mesokatepisternum and ventral $1 / 3$ of mesoanepisternum ; scutum sparsely short setulose except for a bare narrow longitudinal area on each side of a median row of hairs, with a pair of dorsocentral setae; scutellum bearing a pair of long setae, without any other hairs.

Wing hyaline, slightly tinged with brown, all veins yellowish brown. Costa long, costal index 0.61-0. 64; combined length of 2nd and 3rd costal sectors shorter than 1st, 0.84-0. $93 \mathrm{x}$ as long as 1st; 3rd costal sector 0.77-0. 86 of 2nd in length. First costal sector narrow, 1/2 of 2nd one in width. Vein Rs forked. Vein $M_{1}$ starting beyond Rs fork, weakly deflected at its base, curved on proximal $1 / 3$, then nearly straight to tip. Vein $\mathrm{M}_{2}$ weakly curved. Vein $\mathrm{M}_{3+4}$ distinctly bisinuate. Vein $\mathrm{A}$, complete, weakly curved. Costal cilia short, $1.8 \times$ as long as width of 2 nd costal sector. Vein Rs subbasally with a short hair opposite to base of vein $M_{3+4}$. Axillary margin with 6-8 long hairs. Wing membrane trichose. Vein R carrying a group of 10 annular organs at its base and 5-8 ones arranged in a transverse row on its proximal 1/2. Halter yellowish brown. Wing length 3.53-3.94 mm, width 1.64-I. $77 \mathrm{~mm}$.

Legs dark brown. Fore tibia slightly shorter than 1st to 4th tarsomeres together, without a dorsal seta; all tarsomeres longer than wide, equal to each other in width, narrower than tip of fore tibia. Mid tibia bearing 2 weak anterior setae, one of which is inserted at proximal $1 / 3$ and slightly longer than width of the tibia, the other at distal margin and shorter than width of the tibia; the tibia bearing an end-spur and 2 short bristly hairs ventrodistally. Hind femur thickest at its proximal $1 / 5$ in lateral view, then gradually narrowed distally, pilose on ventroproximal portion of its anterior surface; hind tibia bearing 2 weak anterior setae, one of which is at proximal $3 / 7$ and as long as width of the tibia, the other at apex.

Table 1. Relative lengths of leg segments of Triphleba schistoceros sp. nov. 0 .

\begin{tabular}{lccccccc}
\hline & Femur & Tibia & \multicolumn{5}{c}{ Tarsus } \\
& & & 1 & 2 & 3 & 4 & 5 \\
\hline Fore leg & 118 & 100 & 51 & 20 & 18 & 16 & 20 \\
Mid leg & 122 & 111 & 56 & 22 & 22 & 16 & 18 \\
Hind leg & 164 & 156 & 71 & 40 & 31 & 20 & 18 \\
\hline
\end{tabular}

Abdomen black, grayish white pollinose, parallel-sided in dorsal view. All terga wider than long; 1st tergum short, gradually narrowed toward middle, furnished with erect long bristly hairs on its lateral portions; 2nd and 3rd t erga longest, with same length; 4th and 5th terga equal to each other in length, shorter than 6th; 2nd to 6th terga bearing sparse and suberect bristly hairs. 


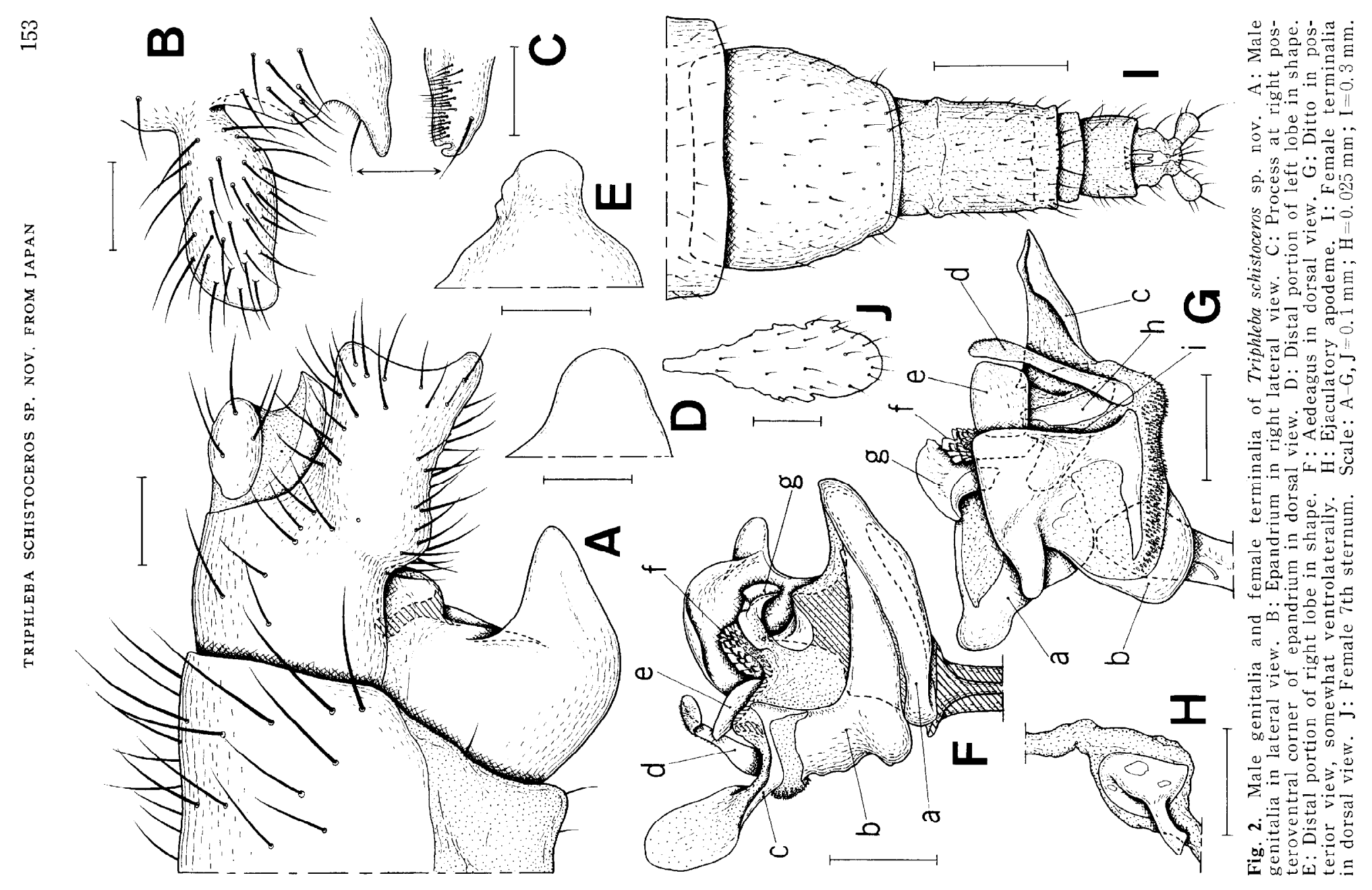


Male genitalia brown. Epandrium grayish white pollinose, large, produced into a short slender process on its right posteroventral corner; the process pointed distally in lateral view, curved inwardly to form a hook-like projection on distal portion, bearing many short hairs on its inner surface. Hypandrium blackish, shining, fused with epandrium on proximal portion, produced into 2 lobes which are membraneous on their proximal portions; right lobe larger than left one, arched, narrowed on transparent distal portion; left lobe flat, rounded on posterior margin. A pair of surstyli completely fused with epandrium, subequal in length to each other; left surstylus rectangular in lateral view, weakly emarginate on posterior margin, produced into a small triangular process on posteroventral corner, the surstylus bearing many bristly hairs on marginal portion and hairs on inner surface; right surstylus slenderer than left one, constricted on proximal portion, bearing many bristly hairs on outer surface and hairs on inner surface. Aedeagus highly asymmetrical in structure, composed of 9 sclerites and bearing minute spinules on its ventral membraneous area; each of the sclerites is here designated by alphabet for description as in Fig. $2 \mathrm{~F} \& \mathrm{G}$; sclerite $a$ ringed in structure, its posteroventral portion produced into a flat plate which is curved dorsally on its distal portion ; sclerite $b$ produced into a broad flat plate on its ventral portion, the plate curved dorsally and bearing a short process on its distal portion; sclerite $c$ being a flat process membraneous on inner surface; sclerite $d$ attaching with membrane on its base, the rest free, pilose on distal $1 / 3$ of outer surface; sclerite e attaching with membrane on its left lateral margin, the rest free, quadrate in shape; sclerite $f$ squamose in structure. Ejaculatory apodeme with a slender process on its median portion. Gonopore opening on membraneous area just at right side of base of sclerite $d$.

Body length : 3.2-3.7 mm.

Female. Differing from male as follows : Compound eye distinctly smaller than in male, 0.60 of head height. Frons 0.66 of head width, longer than in male, $3.1 \mathbf{x}$ as wide as long. Chaetotaxy : Right one of antial setae absent in the specimen ; several short hairs arranged in 2 rows instead of supra-antennal setae. First antennal segment shorter, $1 / 2 \times$ as long as $3 r d$; 3rd antennal segment of ordinary type, globular, as long as wide, with long hairs on distal portion. Arista subapical.

Wing more roundish, more distinctly tinged with brown on marginal portions in cells $\mathrm{r} 5, \mathrm{ml}$ and $\mathrm{m} 2$. Vein $\mathrm{M}_{3+4}$ of right wing of the only examined specimen aberrantly forked on its distal portion. Costal index 0.61 ; combined length of 2nd and 3rd costal sectors 0.71 of 1st in length; 3rd costal sector 0.78 of 2nd in length. Wing length $3.94 \mathrm{~mm}$, width $1.86 \mathrm{~mm}$. Hind femur slender, unlike male, without pilose area.

Abdomen parallel-sided; 1st tergum longer than in male ;2nd, 3rd and 6 th terga subequal in length; 4th as long as 5 th, both shorter than 6th; 6th 

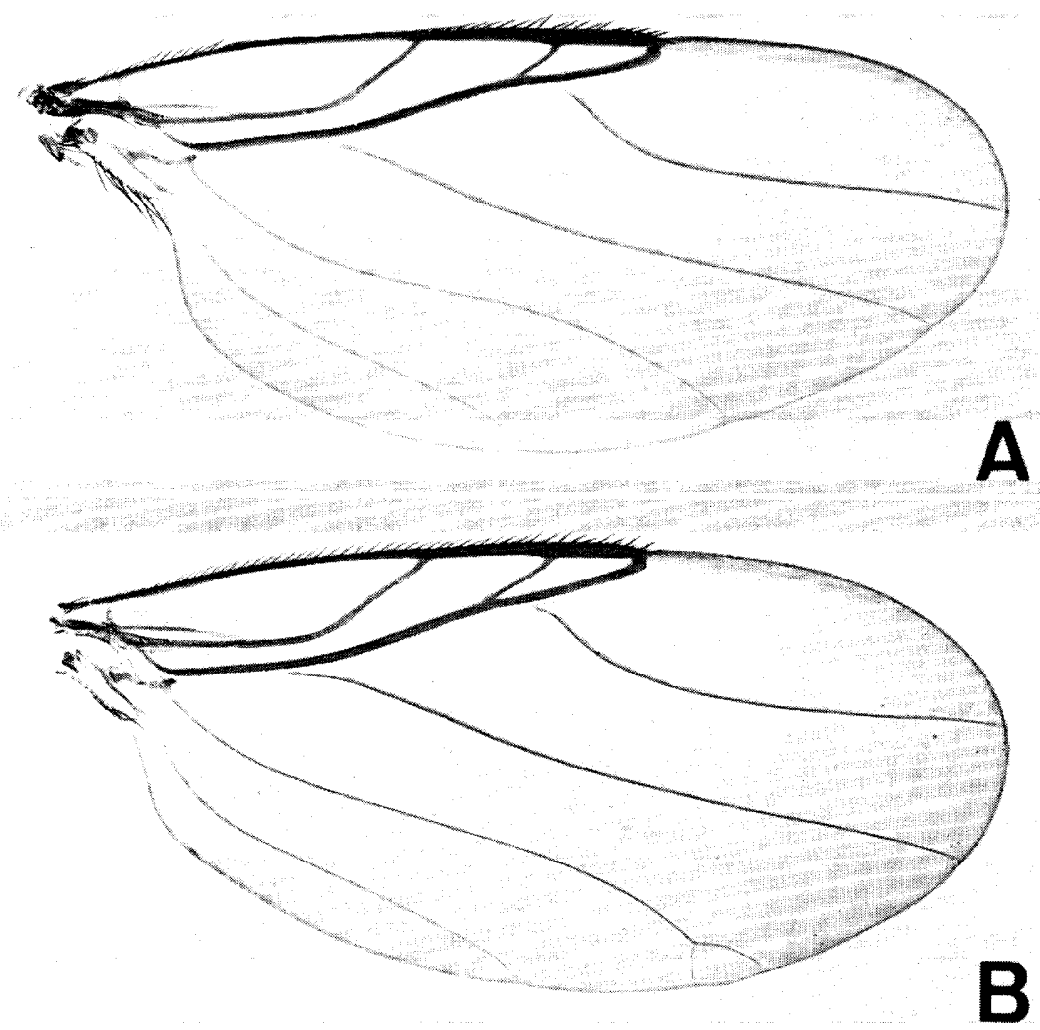

Fig. 3. Wings of Triphleba schistoceros sp. nov. A: Male wing. B: Female wing.

tergum as long as wide, trapezoidal in dorsal view, with weakly rounded lateral margins. Terminalia : Seventh segment membraneous except for sclerotized sternal portion, 7th sternum ovate in shape, with rounded posterior margin ending at posterior margin of the segment ; 8th segment membraneous, lacking tergum and sternum, sparsely short haired; 9th sternum oval; cercus short, thick.

Body length: about $3.2 \mathrm{~mm}$.

ноготур: Male (Type No. 2426, Kyushu Univ.), Mt. Hikosan, Fukuoka Pref., Kyushu, 5. xii. 1969, K. Takeno leg. (Malaise trap).

Paratypes: $1 ठ, 16-18$. xi. 1968; 1 우, 8. xii. 1968; 1 ð, 27. xi. 1969. All were collected by $K$. Takeno at the same locality as holotype.

REMARKS. This new species is easily distinguished from the known species by the bifurcate 3rd antennal segments. It is also characteristic in lacking the anterolateral setae on the head and the dorsal setae on the fore and mid tibiae. So far as we know, these setae are absent only in T.admirabilis Schmitz in the genus Triphleba (Schmitz, 1943, 1949). T. schistoceros is know $\mathrm{n}$ 
from the type-locality only, where it appears in early winter.

\section{References}

Borgmeier, T. 1963. Revision of the North American Phorid Flies. Part I. The Phorinae, Aenigmatiinae and Metopininae except Megaselia (Diptera, Phoridae). Studia Ent., 6: l-256.

Disney, R. H. L. 1982. Re-evaluation of the genus Citrago Schmitz (Dipt., Phoridae) and a consequent secondary homonym. Ent. Mon. Mag., 118: 247-248.

Schmitz, H. 1929. Revision der Phoriden. Berlin und Bonn, F. Duemmler, 211 pp.

— 1941. Phoridae, in Lindner, Die Fliegen der palaearkt. Region, 33: 65-128.

— 1943. Ditto, Ibid., 33: 129-192.

1949. Ditto, Ibid., 33: 193-240.

_ 1951. Japanische Phoriden. Brotéria, 27: 145-158.

Venturi, F. 1966. La struttura morfologica dell'ipopigio di un dittero Foride (Triphleba antricola Schmitz). Frust. Ent., 9: l-42. 